\title{
Journal of Praxis in Multicultural Education
}

Volume 6 | Number 1

Article 2

Spring 2011

\section{Praxis Spring 2011 Title Page}

Follow this and additional works at: https://digitalscholarship.unlv.edu/jpme

\section{Repository Citation}

(2011) "Praxis Spring 2011 Title Page," Journal of Praxis in Multicultural Education: Vol. 6 : No. 1 , Article 2. DOI: $10.9741 / 2161-2978.1048$

Available at: https://digitalscholarship.unlv.edu/jpme/vol6/iss1/2

This Article is brought to you for free and open access by the College of Education at Digital Scholarship@UNLV. It has been accepted for inclusion in Journal of Praxis in Multicultural Education by an authorized editor of Digital Scholarship@UNLV. For more information, please contact digitalscholarship@unlv.edu. 
Volume 6, Number 1, Spring, 2011

ISSN: 2161-2978

\section{The Center for Multicultural Education}

\section{Editors:}

Maria G. Ramirez Porter Lee Troutman, Jr.

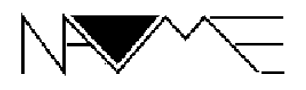

An official Publication of the National Association for Multicultural Education 